Acta Universitatis Nicolai Copernici • Pedagogika XXXVIII/2/2019

Nauki Humanistyczno-Społeczne • Zeszyt 448

DOI: http://dx.doi.org/10.12775/AUNC_PED.2019.014

\author{
Artur Jabłoński \\ Prywatna Szkoła Podstawowa Naja Szkòła \\ Wejherowo \\ ORCID: 0000-0002-3803-1035
}

\title{
NARÓD JAKO (NIE)MOŻLIWOŚć POLITYCZNA \\ REKONSTRUKCJA IDEOLOGII NARODU I PAŃSTWA \\ JANA ROMPSKIEgo
}

\section{Nation as a (un)political opportunity. A reconstruction of the ideology of Jan Rompski's nation and state}

\begin{abstract}
Streszczenie
Artykuł jest próba rekonstrukcji wyobrażenia narodu Jana Rompskiego (1913-1969) - kaszubskiego pisarza, współtwórcy ideowo-literackiej grupy Zrzeszyńców. Wizja narodu kaszubskiego J. Rompskiego skonstruowana jest $\mathrm{w}$ relacji do narodu i państwa polskiego. Ta idea przez długi czas organizowała dyskurs polityczny Zrzeszyńców i samego Jana Rompskiego, który z czasem stał się najważniejszym ideologiem grupy. Pisarz w swym politycznym projekcie o narodzie kaszubskim podkreślał, że identyfikacja narodowa może ulegać zmianom, jednak zawsze charakteryzuje się symboliką, która pozwala narodowi zdefiniować siebie. Zrzeszyńcy do tej symboliki wprowadzili obywatelskość. W ideologii Jana Rompskiego i Zrzeszyńców oznacza to podmiotowe zaangażowanie się Kaszubów równolegle w sprawy własnej wspólnoty narodowej i państwa polskiego.
\end{abstract}

Słow a klucze: Kaszubi, polityczna idea, naród, państwo. 


\section{AbStract}

The article is an attempt to reconstruct the image of the nation Jan Rompski (1913-1969) - a Kashubian writer, co-creator of the ideological and literary group of Zrzeszyńce. J. Rompski's vision of the Kashubian nation is constructed in relation to the nation and the Polish state. This idea for a long time organized the political discourse of Zrzeszyńcy and Jan Rompski himself, who in time became the group's most important ideologist. In his political project about the Kashubian people, the writer emphasized that national identification may change, but it is always characterized by symbolism that allows the nation to define itself. Zrzeszyńcy introduced citizenship to this symbolism. In the ideology of Jan Rompski and Zrzeszyńcy, this means a subjective commitment of the Kashubs simultaneously in matters of their own national community and the Polish state.

Ke y w o r d s: Kashubians, political idea, nation, state.

\section{Wprowadzenie}

W artykule podejmuję próbę rekonstrukcji koncepcji narodu Jana Rompskiego (1913-1969) - kaszubskiego pisarza, działacza, etnografa. Szczególnie interesujące jest to, że w przypadku narodu kaszubskiego jego wyobrażenie Jan Rompski konstruuje w relacji do narodu i państwa polskiego. Moje dociekania prowadzić będę w perspektywie założeń i myśli sformułowanych przez Zrzeszyńców ${ }^{1}$. Była to grupa ideowo-literacka, której zalążek tworzyło Zrzeszenie Regionalne Kaszubów powstałe w 1929 r. w Kartuzach. Ostatecznego kształtu politycznego formacja nabrała w 1933 r., co zbiegło się z decyzją o wydawaniu gazety „Zrzesz Kaszëbskô”2.

1 Za Józefem Borzyszkowskim będę używał formy „Zrzeszyńcy” (kasz.: Zrzeszińcë), choć w literaturze przedmiotu spotkać można także nazwy „Zrzeszeńcy” oraz „Zrzeszowcy”; zob.: Borzyszkowski J., Zrzeszyńcy a Zrzeszenie Regionalne Kaszubów i „Zrzesz Kaszëbskô” w dziejach ruchu kaszubskiego, w: Poezja Zrzeszyńców, opracowanie, wstęp i przypisy J. Borzyszkowski, D. Kalinowski, H. Makurat, Gdańsk 2013.

2 D. Szymikowski, „Zrzesz Kaszëbskô” w latach 1933-1939, Bolszewo 2010, s. $21-31$. 
Osadzenie badań nad myślą Jana Rompskiego w kontekście czasu społecznego i politycznych konfliktów, wobec których stali Zrzeszyńcy, wydaje się konieczne dla uchwycenia procesu kształtowania się poglądów jednego z ważniejszych ideologów kaszubskich drugiej połowy lat 30. oraz dwóch kolejnych dekad dwudziestego stulecia. Jestem przekonany, że taki zabieg metodologiczny pozwoli lepiej zrozumieć konstruowaną przez niego ideologię narodu i państwa. Trzeba podkreślić, że Jan Rompski od początku współtworzył grupę Zrzeszyńców, a będąc najmłodszym z nich, w drugiej połowie lat 30. XX wieku, przejął od Aleksandra Labudy i Stefana Bieszka jej duchowe przewodnictwo. Stąd też - jak się wydaje - literatura Jana Rompskiego przybrała postać pisarstwa zaangażowanego i jednocześnie był/jest to przemyślany projekt polityczny, zdeterminowany kwestiami narodowościowymi. W zamyśle autora, projekt Zrzeszyńców miał rozbudzić narodową świadomość Kaszubów, co odzwierciedla forma i treść utworów Jana Rompskiego.

Prezentowany tekst wpisuje się w problematykę badań kaszubocentrycznych i dostarcza bardziej pogłębionej wiedzy na temat idei narodowej w ujęciu dyskursywnych badań kulturowych ${ }^{3}$. Dyskursywna analiza myśli Jana Rompskiego $\mathrm{w}$ istocie pozwala - na tle ideologii narodu i państwa - prześledzić proces wytwarzania kaszubocentrycznych tożsamościowych projektów indywidualnych i zbiorowych w publicznej przestrzeni kaszubskiej. Jak zauważyła Adela Kożyczkowska:

„Dyskurs wiąże w ten sposób doświadczenie jednostkowe (tu: jednostkowe doświadczenie użytkownika języka kaszubskiego), wprowadza je w obręb własnego języka (struktury swego mówienia) i zmienia istnienie jednostkowego doświadczenia w istnienie dyskursywne. Tym samym człowiek podlega dekonstrukcji, co oznacza, że przestaje być człowiekiem mówiącym po kaszubsku i zaczyna istnieć jako podmiot (Kaszuba) już nie z indywidualną <twarzą>, lecz z uniwersalną indywidualną tożsamością kaszubocentryczną bądź polonocentryczną, bądź nawet niemieckocentryczną"4.

3 A. Kożyczkowska, Kaszubszczyzna. Pedagogicznie o języku i tożsamości, Gdańsk 2019.

4 Tamże, s. 33. 
Przedmiotem moich badań są teksty programowe Jana Rompskiego, tj. artykuły publikowane $\mathrm{w}$ prasie, okolicznościowe referaty, a także notatki autora przechowywane w Muzeum Piśmiennictwa i Muzyki Kaszubsko-Pomorskiej w Wejherowie ${ }^{5}$. Ale najistotniejsze były dla mnie utwory literackie pisarza, jego proza, dramaty i poezja; są one zachowane w rękopisach lub w maszynopisach, większość została wydana drukiem, choć nieopublikowana dotąd pozostaje powieść Jana Rompskiego Wurvanô spjéva ${ }^{6}$.

Na marginesie rozważań powinien dopowiedzieć, że twórczość Jana Rompskiego drukowana była w piśmie „Zrzesz Kaszëbskô” w latach 1933-1939 oraz w powojennej edycji tej gazety, ukazującej się w latach 1945-1947, a także w "Chëczë”, dodatku literackim do tego wydawnictwa. Jedno opowiadanie i fragment utworu Wurvanô spjéva opublikował w latach 70. miesięcznik „Pomerania”; w roku 1970 wyszedł drukiem tomik poezji Pòmión zwònów, a kolejny zatytułowany Wiérzte wydano w 1980 r. Ponadto poezja autora znalazła się we wspólnym z Janem Trepczykiem i Aleksandrem Labudą tomiku Kaszëbskji pjesnjôk z 1935 r. oraz w kilku antologiach wydanych w drugiej połowie XX stulecia i w XXI wieku. W 1987 r. opublikowano dramat Jana Rompskiego Jô chcą na swiat. Niewątpliwie największym osiągnięciem w kontekście wydań twórczości tego autora są dwa tomy serii Biblioteka Pisarzy Kaszubskich: Jan Rompski, Dramaty kaszubskie oraz Poezja Zrzeszyńców w opracowaniu językoznawców, literaturoznawców i historyków z Instytutu Kaszubskiego w Gdańsku.

I druga kwestia, którą muszę podkreślić: życie Jana Rompskiego zbiegło się w czasie z gwałtownymi przemianami, jakim podlegała Europa i świat w XX wieku. Te przemiany nie ominęły też Kaszubów. Musiały zatem odcisnąć swe piętno na Janie Rompskim, który wzrastał w dwudziestoleciu międzywojennym, swą dojrzałość przeżywał w czasie II wojny światowej i dopełnił swego życia w okresie utrwala-

5 J. Kurowska, A. Skwarło, Katalog rękopisów Muzeum Piśmiennictwa i Muzyki Kaszubsko-Pomorskiej w Wejherowie, t. I, Spuścizna Jana Rompskiego, Wejherowo 2005.

6 Muzeum Piśmiennictwa i Muzyki Kaszubsko-Pomorskie w Wejherowie zapowiada druk tej powieści na jesień 2020 r. 
nia się Polskiej Rzeczypospolitej Ludowej. Pisarz nie mógł nie dostrzec dylematów Kaszubów, którzy byli zmuszeni wybierać między polonizacją albo germanizacją, albo własną tradycją, która już w połowie XIX stulecia stała się drogą do „odrodzenia świadomości narodowej wśród Kaszubów”, jak celnie zauważył Gerard Labuda7. Jan Rompski współdzielił przecież los własnej wspólnoty, starając się działać i pisać zgodnie z własnym kulturowym sumieniem i dla kulturowego odrodzenia Kaszubów. Propagowana przez niego idea była przyczyną represji, których autor doświadczył od władz II Rzeczypospolitej, uwięzienia przez faszystów w obozie koncentracyjny Stutthof oraz prześladowań komunistycznej Służby Bezpieczeństwa. Ferdinand Neureiter, autor Historii literatury kaszubskiej, podsumował życiorys Jana Rompskiego w sposób następujący: „Należy on bez wątpienia do najwybitniejszych postaci w literaturze kaszubskiej. Był fanatycznym nacjonalistą kaszubskim i musiał wiele w życiu wycierpieć z powodu swej bezkompromisowości"8.

\section{Zrzeszyńców projekt kaszubskiego odrodzenia narodowego jako polityczny fundament ideologii Jana Rompskiego}

W latach 30. XX wieku Zrzeszyńcy sformułowali oczekiwania wobec inteligencji kaszubskiej, której przypisali rolę sprawczego przywództwa w procesie kulturowego odrodzenia Kaszubów. Teza ta zaważyła na projekcie tożsamościowym, którego sens wyraża twierdzenie, że Kaszubi mają prawo do poczucia własnej odrębności narodowej. Fundamentem tego poczucia jest dziedzictwo Pomorzan, czyli ziemia, język, kultura, historia, mity i wierzenia; jednocześnie Kaszubi są obywatelami Polski i stąd są również spadkobiercami jej dziedzictwa kulturowego. Kaszubi zatem - co logiczne - czują się częścią lechickiej wspólnoty

7 G. Labuda, Podłoże polityczne dyskusji nad autonomia języka kaszubskiego na przełomie XIX i XX stulecia, w: Całe życie pod urokiem mowy kaszubskiej, red. H. Horodyska, Warszawa 1995, s. 23.

8 F. Neureiter, Historia literatury kaszubskiej, Gdańsk 1982, s. 189. 
zachodniosłowiańskiej, czyli Połabian, Polan i Pomorzan. Nie dążą jednak do utworzenia odrębnego państwa9.

Zgodnie z poglądami Zrzeszyńców, Kaszubi utracili swoją państwowość w średniowieczu. W XX wieku wróciły nadzieje na ziszczenie się tzw. „Testamentu Mestwina”"10, czyli politycznego układu Pomorza Wschodniego (Gdańskiego) z Polską (Wielkopolską). Z czasem, w literaturze kaszubskiej, „Testament Mestwina” stał się symbolem braterstwa dwóch lechickich narodów polskiego i kaszubskiego, które miały współtworzyć jedno państwo. Elity polskie w odradzającym się państwie - w latach 20. i 30. - nie podzielały jednak tych poglądów ${ }^{11}$. W tak sformułowanym programie ideowym Kaszubi nie mogli liczyć na wsparcie ówczesnych polskich władz. Administracja młodego państwa polskiego skoncentrowana była na jak najszybszym scaleniu Pomorza z pozostałymi ziemiami przyznanymi Polsce po zakończeniu I wojny światowej. Najprostszym politycznie rozwiązaniem była asymilacja, a nie podkreślanie odrębności kulturowej scalonych ziem. Przyby-

9 Antonina Kłoskowska proponuje, by idee narodu podzielić na te utożsamiające naród z państwem oraz na tzw. ujęcia kulturalistyczne, które uznają związek „między formułującymi się narodami a ich pierwotnym etnicznym podłożem”; zob.: A. Kłoskowska, Kultury narodowe u korzeni, Warszawa 2012, s. 32. Jednakże ze względu na wielość możliwych oglądów współczesne próby zdefiniowania narodów łączą różne koncepcje. Za twórcę takiej nowoczesnej propozycji podejścia do definicji narodu uważany jest Anthony D. Smith, który napisał: „Proponuję zdefiniować naród jako nazwaną wspólnotę ludzką, zamieszkującą ojczystą ziemię, mającą wspólne mity i wspólną historię, wspólną kulturę publiczną, jedną gospodarkę, a także wspólne dla wszystkich członków prawa i obowiązki”; zob.: A. D. Smith, Nacjonalizm, przeł. E Chomicka, Warszawa 2007, s. 25.

${ }^{10}$ Chodzi o polityczną unię Mestwina (pol.: Mściwoj II), księcia wschodniopomorskiego z polskim możnowładcą Przemysławem II. Układ, zawarty w $1282 \mathrm{r}$. w Kępnie w Wielkopolsce, zakładał sukcesję na tronie tego z władców, który przeżyje drugiego. W ten sposób Przemysł II w 1294 r. objął w panowanie Pomorze Wschodnie (Gdańskie), co m.in. pozwoliło mu się koronować na króla Polski.

${ }^{11}$ Jan Rompski kwestii rozumienia przez Zrzeszyńców zagadnienia państwowości - braku dążeń do utworzenia własnego państwa przez Kaszubów - i stosunkowi elit polskich do tych deklaracji Zrzeszyńców, poświęca miejsce w swojej powieści Wurvanô spjéva. Literackiego bohatera powieści najbardziej boli drwina, z jaką „szowjinjiscë polskji” [polscy szowiniści] traktują ideę narodową Zrzeszyńców; zob.: Wurvanô spjéva, sygn. 3, s. 83-84. 
cie polskich urzędników i napływ innych migrantów z Polski w istocie przerodziło się w praktykę sprowadzenia Kaszubów do rangi obywateli drugiej kategorii i wynaradawiania poprzez repolonizację Pomorzan. Częstymi praktykami było szykany przy podziale ziemi w okresie reformy rolnej, a także utrudnianie dostępu do miejsc pracy w budującej się Gdyni. Kaszubów oskarżano o separatyzm, był to w latach międzywojennych, najczęściej zgłaszany przez rodzimą inteligencję pomorską przejaw dyskryminacji. Były też inne akty prześladowań, jak chociażby przymus pracy nauczycieli Kaszubów na ziemiach niekaszubskich, co równało się wymuszonej emigracji poza pomorską ojczyznę ${ }^{12}$.

Wobec powyższego część kaszubskiej inteligencji postanowiła podjąć walkę o prawo do swej tożsamości. Sytuacja polityczna, czyli przybierająca na sile polonizacja Kaszubów i negatywny stosunek do ich języka i kultury - zarówno ze strony endeków, jak i piłsudczyków skłoniła część działaczy Zrzeszenia Regionalnego Kaszubów do politycznego przeobrażenia ruchu kaszubskiego. Otóż Aleksander Labuda, Jan Trepczyk i Jan Rompski oraz zaprzyjaźniony z nimi gdyński robotnik i radny miejski Ignacy Szutenberg zorganizowali się wokół założonej własnymi siłami w 1933 r. gazety „Zrzesz Kaszëbskô”, którą obmyślili jako organ prasowy odnowionego politycznie ruchu kaszubskiego. Na jej łamach Zrzeszyńcy tłumaczyli swój polityczny wybór, pisząc do Kaszubów:

Szukaliście obrony i opieki w różnych partiach i towarzystwach, ale i te nadzieje Was zawiodły. Czy już naprawdę nie ma dla nas Kaszubów żadnej drogi wyjścia, żadnego ratunku? Oto jest tylko jeden ratunek: Pomóc możemy sobie jedynie sami. Jeżeli sami nie stworzymy sobie obrony, to nikt inny nam jej nie da, ani dać nie może. Jeszcze nie jest za późno, ale czas najwyższy, abyśmy nie dali się dłużej tumanić i okłamywać obcym, ale raczej sami zabrali się do pracy nad sobą ${ }^{13}$.

12 J. Kutta, Druga Rzeczpospolita i Kaszubi, Bydgoszcz 2003.

13 Ulotka informacyjna pt. Kaszubi!, poprzedzająca ukazanie się pierwszego numeru gazety "Zrzesz Kaszëbskô”, WAPB, UWP, rep. 4, nr 15293; za: W. Pepliński, Prasa pomorska w Drugiej Rzeczypospolitej 1929-1939, Gdańsk 1987, s. 302-303. 
W ideologii Zrzeszyńców Kaszubi, jako naród słowiański, mieli stać się podmiotem polityki państwa polskiego, co z kolei otwierało im drogę do współrządzenia Pomorzem. Dobrze oddają to słowa:

Żądamy Wolności, Równości Obywatelskiej i Sprawiedliwości.

Żądamy na terenie Kaszub urzędników Kaszubów.

Żądamy starostów Kaszubów.

Żądamy sędziów Kaszubów.

Żądamy inspektorów szkolnych Kaszubów ${ }^{14}$.

Owo braterstwo kaszubsko-polskie - tak istotne dla zrealizowania idei współrządzenia Pomorzem - w praktyce okazuje się niemożliwe z powodu niezrozumienia przez Polaków wewnętrznego świata Kaszubów. Zrzeszyńcy tak o tym pisali:

Głębokie niezrozumienie świata wewnętrznego Kaszubów, spotykane prawie na każdym kroku u braci z innych stron Polski, jest główną przyczyną wszelkiego u nas zła, tą przepaścią dzielnicowości, a zła wola niektórych jednostek jest tegoż drugą przyczyną ${ }^{15}$.

Jako że braterstwo kaszubsko-polskie okazało się niemożliwą do zrealizowania ideą, to Zrzeszyńcy - w początkowej fazie konstruowania projektu narodowego - skupili się na tym, co kaszubskie i skierowali swe postulaty do Kaszubów. Skonstruowali tzw. „drogowskaz narodu kaszubskiego”, czyli „szkołę dla spraw ojczystych”16. Swój program ideowy rozpoczęli od wytłumaczenia Kaszubom dlaczego są oni narodem ${ }^{17}$. „Słowo naród” oznacza, jak pisali: „pewną grupę ludzi zjednoczonych w imię własnej przeszłości, związanych interesami doby obecnej i dążących do wspólnych celów na przyszłość"18. Zdaniem Zrze-

14 Trybuna Ludu Kaszubskiego, „Zrzesz Kaszëbskô”, 1933 r. 1, nr 39, s. 3.

15 Nasz program, „Zrzesz Kaszëbskô” 1933, numer okazowy, s. 1, za: D. Szymikowski, „Zrzesz Kaszëbskô” w latach 1933-1939..., s. 77.

${ }^{16}$ Kaszubi, „Zrzesz Kaszëbskô”, 1933, r. 1, numer okazowy, s. 1.

17 Zob.: D. Szymikowski, „Zrzesz Kaszëbskô” 1933-1939..., s. 130-134.

18 Zagadnienie odrębności narodu Kaszubskiego, „Zrzesz Kaszëbskô”, 1933, r. 1, nr 30, s. 1. 
szyńców Kaszubi bez wątpienia te warunki spełniają. Istotne w myśli Zrzeszyńców było przeświadczenie, że to Kaszubi, a nie kto inny (polscy naukowcy, politycy, autorytety), powinni zdecydować jak chcą się określać. Żyją oni bowiem we własnej idei (dosł. we własnym duchu), przejawiającej się „w odrębnej od polskiej mowie, odrębnych zwyczajach, obyczajach itp."19. Do tej odrębności Kaszubi mają prawo, gdyż gwarantuje im to konstytucja Rzeczypospolitej Polskiej ${ }^{20}$. Upominając się o prawo do życia narodowego dla Kaszubów, Zrzeszyńcy zdawali sobie jednocześnie sprawę z kruchości tego postulatu, gdyż pisali: „Wszyscy Kaszubi wiedzą, że są Kaszubami, ale rzadko który nim jest w samej istocie. Ogół Kaszubów to Kaszubi z nazwy tylko, nieumiejący uzasadnić swej kaszubskości"21.

Projekt ideowy Zrzeszyńców zakładał, że masy kaszubskie wkroczą na szlak, który wskazywał im „drogowskaz”. Tymczasem projekt ten okazał się utopią i formacja wkrótce zrozumiała, że polityczne przebudzenie Kaszubów nie nastąpi z dnia na dzień. Zrozumieli oni, że droga do celu, jakim było odrodzenie narodowe Kaszubów, jest długa i wymaga podjęcia pracy u podstaw. Miały się tego podjąć rzesze przywódców świadomych swej etniczności a także historycznie uświadomieni liderzy, zdolni „pociągnąć” za sobą lud. Realizacja tego postulatu wymagała reorganizacji programu. Początkowo skoncentrowany był on wyłącznie na sprawach politycznych, później poszerzony został o problematykę regionalną, kulturalną, społeczną i gospodarczą. Na łamach „Zrzeszë Kaszëbskji” pisano: „Podkreślamy, że wycofujemy się zupełnie z polityki, gdyż jest ona bez sensu dla Kaszub, skoro nie można jeszcze uprawiać rozumnej, samodzielnej polityki kaszubskiej"22. Tak więc okazało się, że samodzielna kaszubska polityka jest niemożliwa dlatego, iż sprawa ta potrzebuje Kaszubów nie „z imienia”, lecz „Kaszubów z ducha", świadomych swej mocy w działaniu i w celach ${ }^{23}$.

\footnotetext{
19 Tamże, s. 2.

20 Tamże, s. 2.

21 Nasze słońce i nasze cienie [cz. IV], „Zrzesz Kaszëbskô”, 1933, r. 1, nr 36, s. 1.

${ }^{22}$ Kaszubi!, „Zrzesz Kaszëbskô” 1934, r. 2, nr 1, s. 1.

23 Tamże, s. 1.
} 
Na marginesie trzeba dodać, że w praktyce Zrzeszyńcy zaczęli szukać oparcia w sanacyjnych władzach; próbowali nawet włączyć się w budowanie Kaszubskiego Związku Strzeleckiego w Kartuzach ${ }^{24}$. W swej gazecie optymistycznie pisali na temat stosunku rządu do Kaszubów. Jednak w skutek represji ze strony władz państwa ${ }^{25}$ Zrzeszyńcy zmienili zdanie i ponownie - choć już nie wprost - krytycznie zaczęli pisać o relacjach z władzą. W tej skomplikowanej politycznie sytuacji ożywcza dla idei Zrzeszyńców okazała się współpraca z Aleksandrem Majkowskim, który wskazał formacji nowy kierunek rozwoju ideologii. Podstawowym założeniem było przeświadczenie, że duchowa odnowa ludu kaszubskiego jest możliwa tylko poprzez wewnętrzne odrodzenie inteligencji kaszubskiej, która przyjmie na siebie ciężar walki o odrodzenie narodowe.

\section{Idea narodu kaszubskiego jako możliwość do osiągnięcia}

Analiza tekstów Jana Rompskiego pozwala sformułować tezę, iż naród kaszubski - ponad wszelką wątpliwość - ma prawo do samookreślenia kulturowego i zajęcia autonomicznej pozycji pośród innych narodów, nie tylko słowiańskich, europejskich, ale również w skali całego świata. Fundamentem narodu kaszubskiego jest lud, który często bezrefleksyjnie przeżywa swoją odrębność kulturową. Bezrefleksyjność jest wynikiem jego niewykształcenia, stąd też podstawowym zadaniem jest edukacja, gdyż tylko $\mathrm{w}$ ten sposób można poprowadzić ludzi ku idei narodu. Zadanie to spoczywa na prawowiernych wizjonerach, wręcz fundamentalistach, utopistach i entuzjastach takich jak bohaterowie

24 A. Labuda, Kaszubski Związek Strzelecki z punktu naszego widzenia, "Zrzesz Kaszëbskô", 1934, r. 2, nr 12, s. 89.

${ }^{25}$ Chodzi m.in. o przeniesienia służbowe Jana Trepczyka i Stefana Bieszka i konfiskaty nr 17. i 18. pisma z 1934 r., kary grzywny i aresztu dla Aleksandra Labudy i Ignacego Szutenberga; zob.: A. Jabłoński, Robotnik „Zrzeszë Kaszëbskji”. O życiu i działalności Ignacego Szutenberga, Gdynia 2020; zob.: D. Szymikowski, "Zrzesz Kaszëbskô" w latach 1933-1939..., s. 90-105. 
literaccy wykreowani w prozie, poezji i dramatach. Ich zadaniem jest nieustanna walka o odrodzenie narodowe.

Według Jana Rompskiego podmiotowość ludu, tak kluczowa dla procesu odrodzenia, jest możliwa do osiągnięcia poprzez następujące elementy:

1) język, który istnieć ma w świadomości ludu jako fakt lingwistyczny i jednocześnie fakt polityczno-społeczny, czyli naród ma zabiegać o język-mówienie, język-pisanie, język-ortografię, język-czytanie, język-uczenie, język-nauczanie ${ }^{26}$.

2) morze, ziemie i lasy, gdyż określają one terytorium ludu i jednocześnie stanowią wyjątkowe dziedzictwo, co autor podkreśla najczęściej w poezji utrzymanej w duchu romantycznym i neoromantycznym;

3) kulturę duchową i materialną, która postrzegana jest przez lud jako odrębna od kultur innych ludów; czasem zderzona jest z modernistycznymi przemianami zachodzącymi w świecie, co bohaterów stawia niejednokrotnie przed koniecznością dokonywania ważkich wyborów;

4) pamięć historyczna, która jest pamięcią wspólną, co pozwala ludowi rozpoznać własną ojczyznę w jej przeszłości;

5) obywatelskość, polegającą na podmiotowym zaangażowaniu się ludu w sprawy własnej wspólnoty narodowej i własnego państwa, które stanowi sumę kultur regionalnych/narodowych swego terytorium.

W myśleniu Jana Rompskiego - tak samo jak w przypadku myśli innych Zrzeszyńców - ważnym ogniwem w procesie wytwarzania narodu jest inteligencja, to ona odpowiada za pracę ideową, a jej narzędziem jest literatura. Za pomocą literatury Jan Rompski chciał krzewić bliskie mu ideały i pragnął przemienić Kaszubów ze zobojętniałych na wyższe, idealistyczne wartości, na wspólnotę odpowiedzialną za własny byt narodowy. Podmiotowość nie mogła się jednak budować na fundamencie realizmu, ponieważ realizm może zniewalać idealizm, a to może

26 Zob.: A. Kożyczkowska, Kaszubszczyzna..., s. 86. 
utrudniać poznanie dóbr duchowych, płynących z własnej kultury. Toteż w ideologii Jana Rompskiego filarem podmiotowości wspólnoty jest własne „bycie” jej członków, zawsze jednak poprzez ogólnoludzki idealizm i poprzez związki z ideami własnej kultury, o czym tak pisał:

V svjece feleje dejalezmu. Dejalëzm, choci rodzi czasem lëdzi njekompletnech, kjej je zmjiloni, jednak procimko pchô lëdzkosc v remjona vëszsziho żëcô. To je jeho dobrota: rozklivô kulterę dechovą. Dze won żëcé farvji tam wubetk, stateczność je. Człovjek go muszi mjec, jele straci, traci svoje vortnotę i czëcé rzesznjiho. Dejalëzm nji może bëc wobsadłi przez rozem. Ten wostatni nje je skuńczoni i za vjolgji budzi egojizm procimko do dejalëzmu, chteren mô znankji altrujisteczni, kjej movjimë wo znjiżonim do bleższi javernotë; bezgreńcovi dejalëzm mô znaczenji woglovo lëdzkji, nje zveskovni tam, dze jidze nopjervi wo społeczeństwo v państvje czë norodze. (...) Tu jidze wo vërobjenjé przez vëszszą kulterę intelektualną svjadomoscë svojiho bëcô dlo retenku całosce, wo vëtvorzenjé dejalezmu zafarvjoniho intelektualezmę. (...)

Wu naju dovô sę vjidzec dzisi też gvesni dejalezm. Stvorzël go ruch kaszëbskji. Nje je won teli z procesu kulturë jintelektualni, jak romantikji, choci nje czesto wodervani. To je njebezpiecznota, bo wunjosłi tą możemë zabec wo fudameńtach, jakim je lud. Nje znaczi to, żebe przednjictvo mjało nagjibac sę czësto do lëdu. Nje. Ale do jeho javernote! Ko lud żëje choci njiższim vëwobrażenjim dejału. Wodepchnjenjé go tvorzi zastojenjé vszëdni tvorznotë, a lud takji razem $\mathrm{z}$ jeho wodcama vsadzec be mog v szklaną szafę abo żelazną klodkę i vësłac do muzeum czë jiniho przedstovjecelstva martvotë! Tvorzmë z Ledę, dlo jeho rozklecô! ${ }^{27}$.

[Na świecie brakuje idealizmu. Idealizm choć czasem rodzi ludzi niekompletnych, kiedy jest źle rozumiany, to jednak nade wszystko popycha ludzkość w ramiona wyższych form życia. Jego zasługą jest to, że rozwija kulturę duchową. Tam, gdzie on życie barwi, tam jest pokój i dostatek. Człowiek go musi posiadać, jeśli straci, straci też poczucie własnej wartości i związku z innymi. Idealizm nie może być zniewolony przez rozum (realizm). Ten ostatni nie jest uformowany dostatecznie i zbyt wielki rodzi egoizm w przeciwieństwie do idealizmu, który charakteryzuje się ce-

27 J. Rompski [Rębjok], Rozmiszlanjé na pargu kaszebjiznë, „Zrzesz Kaszëbskô", 1938 nr 7, s. 46-47. 
chami altruizmu, kiedy mowa o relacji z bliższą rzeczywistością; bezgraniczny idealizm ma znaczenie ogólnoludzkie, nie szuka zysku tam, gdzie w pierwszej kolejności idzie o społeczeństwo w państwie czy narodzie (...). Chodzi wytworzenie poprzez wyższą kulturę intelektualną świadomości swojego istnienia (bycia) dla ratowania całości, o wytworzenie idealizmu zabarwionego intelektualizmem (...).

U nas można już dziś zauważyć własny idealizm. Stworzył go ruch kaszubski. Nie tyle wziął się on z rozwoju kultury intelektualnej, ile z romantyzmu, choć niezupełnie jest oderwany. Niebezpieczeństwo tego jest takie, że niesieni romantyzmem możemy zapomnieć o fundamentach, jakie stanowi lud. Bynajmniej nie oznacza to, by liderzy mieli zupełnie nagiąć się do ludu. Nie. Ale do jego rzeczywistości. Przecież lud żyje, choć i z wątłym wyobrażeniem ideału. Odepchnięcie go prowadzi do zatrzymania wszelkiej twórczości, a lud taki wraz z jego liderami mógłby zostać zamknięty w szklanej szafie albo w żelaznej klatce i wysłany do muzeum czy innego wyobrażenia martwoty! Twórzmy z ludem, dla jego rozwoju! $\left.{ }^{28}\right]$.

Jan Rompski osadza ideę narodu na konfrontacji realizmu/rozumu i idealizmu. Społeczeństwo (czyli lud) nie może samo siebie sprowadzić do relacji społecznych opartych na realizmie/rozumie, gdyż to rodzi egoizm. Więcej, dla Jana Rompskiego społeczeństwo wyłącznie reali$\mathrm{zmu}$ /rozumu to społeczeństwo pozbawione pierwiastka życia, stąd też jeśli społeczeństwo ma być wspólnotą żywych, to z konieczności potrzebuje idealizmu i idei tworzonej przez rodzimych intelektualistów.

\section{Wspólne państwo Kaszubów i Polaków jako polityczna (nie)możliwość}

Jan Rompski swe myślenie o państwie osadza na twierdzeniu,, że kaszubska tożsamość narodowa może się konstruować tylko w relacji do narodu i państwa polskiego. Sens tak konstruowanej tożsamości opiera się na podobieństwach i jednocześnie na różnicach między narodami polskim i kaszubskim, i co istotne - tylko w ten sposób może się manifestować kaszubska odrębność. Tylko nieustanne porównania

28 Wszystkie przekłady z języka kaszubskiego - Artur Jabłoński. 
i konfrontacje kultur obu narodów, które autor uznaje za równe sobie, wytwarzać mogą świadomość wspólnotowości kaszubskiej. Jednocześnie w ideologii Jana Rompskiego wspólnota narodowa Kaszubów nieustannie musi o swoją podmiotowość zabiegać, a nawet walczyć.

Podmiotowość kaszubska - jak zdaje się to potwierdzać biografia Jana Romskiego - nie może się konstruować inaczej jak poprzez to, co polskie i to, co kaszubskie. Pierwsze jest wynikiem zaangażowania w sprawy polskie, co jest związane choćby z tym, że formalna edukacji Kaszubów jest zawsze (od 1920 r.) edukacją polską. Wiara Kaszubów może się realizować tylko w takim kościele, który będzie kojarzony z polskością, a więc tylko w Kościele Katolickim. Wszystkie swoje sprawy prawne, administracyjne i inne Kaszubi „załatwiać mogą” tylko w urzędach polskich. Drugie - jest efektem atencji dla sprawy kaszubskiej, a ta potrzebuje ciągłego kształtowania poprzez kaszubskie autorytety, którymi mogą być twórcy literatury, ale mogą one być też dostarczane poprzez literaturę. Jeśli idzie o twórców literatury, to dla Jana Rompskiego takim autorytetem był bez wątpienia Aleksander Majkowski ${ }^{29}$.

Podmiotowość kaszubska potrzebuje być kształtowana poprzez idee kaszubskie, a tych nośnikiem jest literatura kaszubska; ale podmiotowość ta potrzebuje także być kształtowana poprzez idee polskie, a tych z kolei dostarcza Kaszubom literatura polska. Jednak świadomość kaszubska nie może być wyłącznie zdominowana ideami polskimi, gdyż to może być dla kaszubskiej tożsamości raniące. Stąd zapewne myśl Jana Rompskiego jest swoistą wypadkową idei polskich, które z czasem zostały zrównoważone oddziaływaniem modernizmu kaszubskiego (literatura Młodokaszubów) i zaangażowanego pisarstwa kaszubskiego dwudziestolecia międzywojennego (literatura zaangażowana Zrzeszyńców) ${ }^{30}$. Autor tak o tym pisze:

29 Jan Rompski podkreśla to przy wielu okazjach, nie tylko w swojej twórczości literackiej, ale też publicystycznej; zob.: J. Rompski, O literaturze kaszubskiej, „Zrzesz Kaszëbskô”, 1946 nr 6, s. 1-4.

30 Feliks Marszałkowski, inny przedstawiciel Zrzeszyńców, podobnie postrzegał działalność i pisarstwo Rompskiego: „Chciał utrzymać Kaszuby przy życiu, wpoić im duszę narodową, wpoić im przekonanie, że mają walory do uzyska- 
Jedno miôł jem lubienié

W szkòłowi knôpa ławie:

Czëtac snôżé spiéwanié

Pòétów naj ò sławie.

Jakbë mie na gùslë grôł,

Plachcôl chtos dëszã w tãgach,

W malarszczich ją farbach brôł,

Jak w Słowacczégò ksãgach...

Lërą zarzek Hejka mie!

Remùsa kôłpiów szorë

Czëł jem nocą w cëchim snie,

Jak czejbë grałë bòrë...

Zemia w mie tak òdecknie!

Bòrënk òdkôrbiém jejich:

Kaszëbską chto rozmieje,

Niech żëje w spiewach mòjich ${ }^{31}$.

[Jedno miałem kochanie

W szkolnej chłopca ławce:

Czytać piękne pieśni

Poetów naszych o sławie.

Jakby mi na gęślach grał,

Znaczył ktoś duszę w tęczach,

W malarskich ją farbach przedstawiał,

Jak w Słowackiego księgach...

Lirą oczarował Heyke mnie!

Remusa łabędzi głębiny

Słyszałem nocą w cichym śnie,

Jakby to grały bory...

Ziemia obudzi się we mnie!

nia autonomii kulturowej, że mają swoją rację bytu tak dla siebie, jak i dla Polski"; Jan Rompski w rozważaniach Feliksa Marszałkowskiego, w: K. Muza, Portret pisarza i regionalisty kaszubskiego, Praca magisterska napisana pod kierunkiem prof. dr. Andrzeja Bukowskiego, Uniwersytet Gdański 1979, za: A. Skwarło, Życie i twórczość Jana Rompskiego, w: Katalog rękopisów Muzeum Piśmiennictwa i Muzyki Kaszubsko-Pomorskiej $w$ Wejherowie, red. J. Kurowska, A. Skwarło, tom I, Spuścizna Jana Rompskiego, Wejherowo 2005, s. 109.

31 J. Rompski, Lubienié, w: Modra struna. Antologia poezji kaszubskiej, red. W. Kiedrowski, Gdańsk 1973, s. 125. 
Młodzieniec odpowiedzią ich:

Kaszuby kto rozumie,

Żyć będzie w pieśniach moich].

Państwowość wymaga od Kaszubów przede wszystkim świadomości swojej ziemi-ojczyzny, która jest niczym innym jak poczuciem konieczności działania dla rozwoju kaszubskiego języka, tradycji, kultury, narodu. Stąd w konstruowanej idei Jana Rompskiego słowo „Kaszëbskô” (użyte w bierniku w wersie: „Kaszëbską chto rozmieje”) znaczy to samo, co „Pòlskô”, o czym Bernard Sychta tak pisał: „Nazwa Kaszëbskô należy do tej samej formacji słowotwórczej, co nazwa Pòlskô"32.

Aby lepiej zrozumieć sens pojęcia „Kaszëbskô” warto odnieść je do pojęcia „Polska”. Semantycznie pojęcie „Polska” jest wieloznaczne: „Polska” może być konturem na mapie, określeniem geograficznym lub administracyjnym. Dla większości Polaków „Polska” będzie jednak zawsze kojarzyć się z ojczyzną, z państwem, a w czasach, gdy tego państwa nie było, „Polska” kojarzona była z symbolem wolności. „Polska” oznacza także ludzi - Polaków. Dokładnie tak samo wieloznaczne jest pojęcie „Kaszëbskô”. Jan Rompski nie użył w swym tekście pojęcia „Kaszëbë", które zwykle używane jest jako pojęcie geograficzne i nie sięgnął też po pojęcie „kaszëbizna”, gdyż ono najczęściej rozumiane jako język, choć może być też użyte w szerszym rozumieniu i wówczas określa kulturę Kaszubów. Autor świadomie - na potrzeby swej idei - wybrał wieloznaczeniową „Kaszëbskô”, tylko bowiem w ten sposób mógł dopodmiotowić Kaszuby i Kaszubów. To zaś było/ jest niezbędne, aby możliwa stała się - także w praktyce politycznej - idea wspólnej kaszubsko-polskiej państwowości.

Polityka symetrii kaszubsko-polskiej każe zatem na nowo przemyśleć tezą o jedności kultury polskiej i kaszubskiej na rzecz swoiście, bo wewnętrznie zróżnicowanego konstruktu ideologicznego. W ideologii Jana Romspskiego jest to kolejna próba wewnętrznego ułożenia kaszubsko-polskich relacji, które muszą się (zre)konstruować w nowej

32 Sychta B., 1968-1976: Słownik gwar kaszubskich na tle kultury ludowej, Wrocław 1970, t. III, s. 47. 
rzeczywistości społeczno-politycznej, odnosząc się jednak do wcześniejszej młodokaszubskiej tezy „co kaszubskie, to polskie”33.

Poniekąd chodzi o (nie)gasnącą wiarę Jana Rompskiego w to, że możliwa jest wolnościowa kaszubsko-polska relacja, której logika osadza się na politycznej symetrii i autonomii obu narodów we wspólnych państwie. Co ważne, ideologia Jana Rompskiego było odpowiedzią na narastające niepokoje polityczne lat 30 . dwudziestego wieku. W istocie jest to jednak utopia polityczna i najpełniej dochodzi ona do głosu w powieści Wurvanô spjéva, w której jeden z bohaterów mówi:

Boli mje kożdo ji rena, bo móm ji żëłë, le krev płenje Pomorzôka, chterną dóm ji czej mdze potrzéb. Leno skomę móm za novą, spraviedlëvą, na vzajemni róvnoscë pravóc vszëtczich narodów, zbudacëję narodów słovjańsczich, złączoni wunią gospodarczą z jinyma narodama sviata. Niech kòżdi zgódno ze svòjim dëchę klëje kulturę svoją. Njech provadzi svoję politikę zrozmienjô woglovégò dobra. Bële kożdi czëł sę wolni, czëł spraviedlëwą wopjekę prava, czej mdze konieczné ${ }^{34}$.

[Boli mnie każda jej rana, bo mam jej żyły, tylko krew płynie Pomorzanina, oddam ją dla niej, jeśli zajdzie taka potrzeba. Pragnę jedynie nowej, sprawiedliwej, opartej na wzajemnych prawach wszystkich narodów, ze wspólnotą narodów słowiańskich, złączonej unią gospodarczą z pozostałymi narodami świata. Niechaj każdy w zgodzie z własnym duchem kuje swą kulturę. Niechaj prowadzi własną politykę zrozumienia dobra wspólnego. Byle każdy czuł się wolny, czuł sprawiedliwą opieką prawa, kiedy zajdzie taka potrzeba].

33 Hasło sformułowanego przez Młodokaszubów na początku XX w. „Co kaszubskie, to polskie" wyrażało wolę współistnienia Kaszubów z Polakami w jednym państwie, o którym marzyły elity intelektualne obu narodów. Podczas konferencji pokojowej w 1919 r., kończącej pięcioletnie zmagania wojenne, Kaszubi optowali za włączeniem Pomorza Wschodniego w granice odradzającej się Rzeczypospolitej. Nastąpiło to ostatecznie 10 lutego 1920 r. Hasło Młodokaszubów oni sami odnosili do historycznego układu „na przeżycie” zawartego w 1282 r. pomiędzy wschodniopomorskim księciem Mściwojem II a księciem wielkopolskim Przemysłem II.

34 J. Rompski, Wurvanô spjéwa, rękopis znajdujący się w Muzeum Piśmiennictwa i Muzyki Kaszubsko-Pomorskiej w Wejherowie, dział rkps., sygn. 3, s. 125. 
Ostatecznie utopia politycznej symetrii kaszubsko-polskiej, a więc utopia wolnych narodów we wspólnych państwie, w myśli Jana Romskiego zanika w okresie Polski Ludowej. Jest ona co prawda obecna $\mathrm{w}$ jego poglądach jeszcze $\mathrm{w}$ latach 40 ., a nawet 50. XX stulecia. Przestała być jednak przedmiotem ideowego sporu przestrzeni publicznej. W jej miejsce „wchodzi” refleksja skupiająca się na własnej ziemi, wspólnocie i przyszłych pokoleniach. W pewnym sensie Jan Rompski żegna swoją utopię jako niemożliwy do zrealizowania projekt polityczny. Chyba najpełniej sytuację tą oddaje wiersz Naji dukt $t^{35}$, który ze względu na polityczną ważność dla dokonanej dekonstrukcji ideologii Jana Rompskiego przytaczam w całości:

Przez Kaszëbë kòchóm cebie,

Przez Kaszëbë twòrzã tobie,

Przez nie dlô mie môsz le jestã

Pòlskò! Nie òdpichôj mie...

Jô le mòcnym serca kòchóm

Jak mój lud, kórną wiérztą

Tczã ce, w sercu ce nie niechóm

Pòlskò! Tak lud równak chce...

Czó! Dze mòrze graje,

Rëczi ë szuńcô,

Wëcygô w sztrąd paje

W gromistim tuńcu.

Stądka szed nowi dlô ce wid.

Lãpã tam trzimôl mój lud.

Wëzdrzë jak tóniô w sluńcu sklëni,

Slëchôj jak chlupkô i jak dërżi

W ulubienim swégò lądu

W sławie wieczny tegò sztrądu!

Pòlskò! Rozmiejesz të ten spiéw?

Tëc tam serc je naszëch zéw!

Jô milotny spiéwóm chorôł

Naj parłãcznëch serc,

Co jak słuńce bądze gòrôł

Na wiek nie czwierc!...

35 J. Rompski, Wiérztë, Gdańsk 1980, s. 139. 
Zdrzë tam dzeckò, zdrzë tam starënk -

Splotlë rãce w jeden łãk,

To na wôłtôrz twój naj dôrënk,

Na ùlżenié twòjëch mãk.

Pòkąd wiarë, pòkąd mòwë.

Tak mdã turzëł jak mój lud.

Przenëkóm jô wszedny mòre,

Strzisã Strach, Niewôrto, Trud...

Czej'm dzecynné przescyg lata,

Zdrzôł jem w nieba chmurny blôs -

Chcôł jem nądka duńc do swiata

Dobëc dësz snôżëch krôs.

Tej mie mòja w sercu zemia,

Grużel swòją zmiesza z krwią.

Dësza cëchò jakbë stamia,

Pierszą spłënã bólu łzą.

I jem pòznôl òjczëznã

I jem pòznôł co je lud,

Swjãtszą sta sã Tatczëzna!

Wierzec òprzestôl jem w cud!...

[Przez Kaszuby kocham ciebie

Przez Kaszuby tworzę tobie

Przez nie dla mnie masz sens bycia

Polsko! Nie odpychaj mnie...

Ja tylko mocnym sercem kocham

Jak mój lud, kornym wierszem

Czczę cię, z serca nie wyrzucam

Polsko! Tak lud przecież chce...

Słuchaj! Gdzie morze gra,

Ryczy i grzywy fal wznosi,

Wyciąga na brzeg łapy

$\mathrm{W}$ wielkim tańcu.

Stąd wyszło dla ciebie nowe światło.

Lampę tam trzymał mój lud.

Popatrz jak toń w słońcu lśni,

Słuchaj jak pluska i jak drży,

Zakochane w swoim lądzie,

$\mathrm{W}$ wiecznej sławie tego brzegu!

Polsko! Czy rozumiesz ten śpiew? 


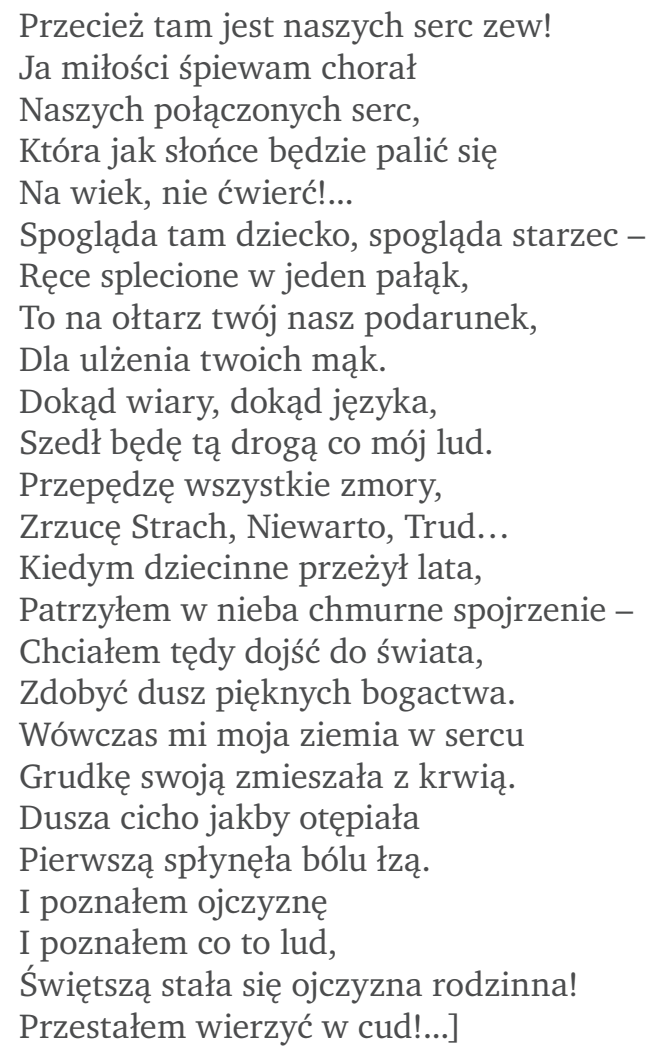

\section{Zakończenie}

Idea kaszubskiej odrębności kulturowo-narodowej to jądro ideologii Jana Rompskiego. Jej realizacja jest możliwa tylko poprzez walkę o odrodzenie i trwanie kaszubskiej wspólnoty. Jan Rompski krytycznie przemyślał kwestię jedności kultury polskiej i kaszubskiej, na której swój program zbudowali kaszubscy moderniści. W efekcie tego kulturowa jedność przestała być priorytetem utopii politycznej Jana Romskiego, podobnie jak przestała zasilać program Zrzeszyńców.

Politycznie innowacyjna - w okresie międzywojennym i powojennym - była koncepcja państwa polskiego, którą Jan Rompski osadzał na fundamencie jedności państwowej dwóch odrębnych i równorzęd- 
nych narodów. Jest to idea, która przez długi czas organizowała dyskurs polityczny ideowo-literackiej grupy Zrzeszyńców i samego Jana Rompskiego, który z czasem stał się jej najważniejszym ideologiem. Jednakże w przytoczonym wcześniej wierszu Naji dukt, Jan Rompski żegna się z własną utopią; ta zamiera w skutek zatrzymania się Kaszubów w drodze własnego narodowego rozwoju. Narodowy rozwój jest warunkiem koniecznym wspólnego kaszubsko-polskiego życia w państwie polskim. Jednocześnie polityka władz państwa nieustannie dążyła do zepchnięcie pomorskiej ludności rodzimej do statusu mniejszości narodowej w ojczyźnie Polaków.

Jan Rompski w swym politycznym projekcie o narodzie kaszubskim podkreślał, że identyfikacja etniczna i/lub narodowa, choć może ulegać zmianom, to jednak charakteryzuje się symboliką, która pozwala grupie etnicznej/narodowi zdefiniować siebie. Polityczna przynależność to zatem sprawa takich symboli jak język (pismo), terytorium, religia (wyznanie), historia, literatura, bohaterowie. Ideowym osiągnięciem Zrzeszyńców jest to, że wprowadzi oni obywatelskość do symboliki, pozwalającej Kaszubom definiować siebie. Sama zaś obywatelskość w ideologii Jana Rompskiego i Zrzeszyńców to nic innego jak podmiotowe zaangażowanie się Kaszubów w sprawy własnej wspólnoty narodowej i państwa polskiego.

\section{Bibliografia:}

Borzyszkowski Józef, Zrzeszyńcy a Zrzeszenie Regionalne Kaszubów i „Zrzesz Kaszëbskô" w dziejach ruchu kaszubskiego, w: Poezja Zrzeszyńców, opracowanie, wstęp i przypisy J. Borzyszkowski, D. Kalinowski, H. Makurat, Gdańsk: Instytut Kaszubski, 2013.

Jabłoński Artur, Robotnik „Zrzeszë Kaszëbskji”. O życiu i działalności Ignacego

Szutenberga, Gdynia: Wydawnictwo Region, 2020.

Kaszubi, „Zrzesz Kaszëbskô”, 1933, r. 1, numer okazowy.

Kaszubi!, „Zrzesz Kaszëbskô” 1 (1934). 
Kiedrowski Wojciech, red., Modra struna. Antologia poezji kaszubskiej, Gdańsk: Wydawnictwo Morskie, 1973.

Kłoskowska Antonina, Kultury narodowe u korzeni, Warszawa: Wydawnictwo Naukowe PWN, 2012.

Kożyczkowska Adela, Kaszubszczyzna. Pedagogicznie o języku i tożsamości, Gdańsk: Wydawnictwo Uniwersytetu Gdańskiego, 2019.

Kurowska Janina, Skwarło Anna, Katalog rękopisów Muzeum Piśmiennictwa i Muzyki Kaszubsko-Pomorskiej w Wejherowie, t. I, Spuścizna Jana Rompskiego, Wejherowo: MPiMKP, 2005.

Kutta Janusz, Druga Rzeczpospolita i Kaszubi, Bydgoszcz: Pozkal, 2003.

Labuda Aleksander, Kaszubski Związek Strzelecki z punktu naszego widzenia, „Zrzesz Kaszëbskô”, 12 (1934).

Labuda Gerard, Podłoże polityczne dyskusji nad autonomia języka kaszubskiego na przełomie XIX i XX stulecia, w: Całe życie pod urokiem mowy kaszubskiej, red. H. Horodyska, Warszawa: Komitet Historii Nauki i Techniki PAN, Wydawnictwo Retro-Art, 1995.

Nasz program, „Zrzesz Kaszëbskô” 1933, numer okazowy.

Nasze stońce i nasze cienie [cz. IV], „Zrzesz Kaszëbskô”, 1 (1933).

Pepliński Wiktor, Prasa pomorska w Drugiej Rzeczypospolitej 1929-1939, Gdańsk: Wydawnictwo Morskie, 1987.

Rompski Jan, Wurvanô spjéva, rękopis w zbiorach Muzeum Piśmiennictwa i Muzyki Kaszubsko-Pomorskiej, sygn. 3.

Rompski Jan [Rębjok], Rozmiszlanjé na pargu kaszebjiznë, „Zrzesz Kaszëbskô", 7 (1938).

Rompski Jan, O literaturze kaszubskiej, „Zrzesz Kaszëbskô” 6 (1946).

Rompski Jan, Wiérztë, Gdańsk: Zrzeszenie Kaszubsko-Pomorskie, 1980.

Rompski Jan, Dramaty kaszubskie, oprac., wstęp i przypisy A. Kuik-Kalinowska, D. Kalinowski, J. Treder, Wejherowo-Gdańsk: Muzeum Piśmiennictwa i Muzyki Kaszubsko-Pomorskiej i Instytut Kaszubski, 2009.

Skwarło Anna, Życie i twórczość Jana Rompskiego, w: Katalog rękopisów Muzeum Piśmiennictwa i Muzyki Kaszubsko-Pomorskiej w Wejherowie, red. J. Kurowska, A. Skwarło, tom I, Spuścizna Jana Rompskiego, Wejherowo: MPiMKP, 2005.

Smith Anthony D., Nacjonalizm, przeł. E Chomicka, Warszawa: Wydawnictwo SiC!, 2007. 
Sychta Bernard, Stownik gwar kaszubskich na tle kultury ludowej, t. I-VII, Wrocław: Zakład Narodowy im. Ossolińskich - Wydawnictwo PAN, 1968-1976. Szymikowski Dariusz, „Zrzesz Kaszëbskô” w latach 1933-1939, Bolszewo: Biblioteka Gminy Wejherowo, 2010.

Trybuna Ludu Kaszubskiego, „Zrzesz Kaszëbskô”, 39 (1933).

Zagadnienie odrębności narodu Kaszubskiego, „Zrzesz Kaszëbskô”, 30 (1933). 